IRSH 56 (20I I), Special Issue, pp. I 25 -I 40 doi:10.1017/S00208590 I 100054X (C) 20I I Internationaal Instituut voor Sociale Geschiedenis

\title{
The Religious Aspect of Labour Ethics in Medieval and Early Modern Russia*
}

\author{
A R K A DIY E. TARASOV \\ Faculty of History, Lomonosov Moscow State University \\ E-mail: tarasov@histmsu.ru
}

\begin{abstract}
Summary: This article analyses the basic feature that defined Russian labour ethics in medieval and early modern times - its religious aspect. There are two main elements to the subject. First, the role of Eastern Christianity and Church tradition in labour regulations, and second, the realities of everyday life in Russia and the historical peculiarities of the Russian locale, its natural conditions and climatic features, which had an influence on working activity. Until the time of Peter the Great, the labour ethics of the Russian Orthodox Church saw no significant change, and their main content could be defined as an educational process.
\end{abstract}

In the late medieval and early modern period, acute change and expansionist activity can be found in western Europe, while other regions appear to have been more static or perhaps passive. The period was marked in western Europe by certain characteristic features: the Renaissance, with its humanist ideology, a great upsurge in art and a stirring of scientific enquiry; the Age of Discovery, or the Age of Exploration; the Protestant Reformation; and the rise of a new economic system - capitalism. The Russian state was removed from most of those developments. Certainly, some trends from western Europe reached Russia during those times, but Russia as a whole continued to live according to its existing traditions, based in social and economic terms on feudalism, and in spiritual and ideological terms on Russian Orthodoxy, with its characteristic system of values. Those traditions were not entirely rigid, and there were changes at the margin, but such powerful upheavals as occurred in western Europe never took place in Russia.

Generally speaking, the issue of Russian labour ethics remains poorly studied, as generations of Russian scholars from the eighteenth to the beginning of twentieth centuries had no sense of it being an inherently worthwhile subject. In spite of a basic orientation towards social and economic problems, Soviet historiography always concentrated on the

\footnotetext{
* I am grateful to Svetlana Ryabova for her assistance in preparing this article.
} 
study of other questions concerning the history of labour relations, and above all on the class struggle. It is only recently that historians have gradually begun to apply themselves to questions of labour ethics, and no definitive conclusions can therefore yet be drawn.

In view of that, this article will concentrate on the basic theme which has defined Russian labour ethics in medieval and early modern times - its religious aspect. To do so it has been necessary to set out certain basic requirements. First, we must explain the general characteristics of Orthodox attitudes to work and compare those with the attitudes of the Church's Western Christian counterpart. Second, we must identify Russian texts containing thoughts on work ethics and trace through them the path of the influence of religious aspects of labour ethics in medieval and early modern Russia. Chief importance among such texts will be ascribed to the Domostroi - a key source of information on the Russian household. Third, it is necessary to show the role of monastic tradition in the formation of labour ethics. The fourth and final task is to identify the position of work and the worker in wider society.

\section{THE RUSSIAN ORTHODOX CONTEXT}

Religion had a very strong influence on human consciousness in medieval and early modern Russia, just as it had in the entire Christian world during the same period. Because people everywhere were indoctrinated with the idea that a Superior Being directed the energy of men on the route towards salvation, ${ }^{\mathrm{I}}$ a thorough examination of representations of work and labour relations in the period is possible only if we take the religious sphere into consideration.

In Russia [in medieval times: Rus'] the articles of faith and canons of Eastern Christianity were guarded by the Russian Orthodox Church, which was founded at the end of the tenth century. The Church played a significant role in the life of medieval Russian men and women, being seen as a representation of the divine presence. At the same time, there were large differences between the rules as contained in the articles of faith on the one hand and social practices on the other. Still, high-ranking Church officials - bishops and abbots - exerted a strong influence on social life. Those who lived in accordance with Christian ideals were highly revered by ordinary people. They included, first and foremost, hermits, and especially fools for Christ. ${ }^{2}$

I. There are many publications devoted to this matter. See, for example, E. Starbuck, The Psychology of Religion: An Empirical Study of the Growth of Religious Consciousness (New York, I9I I); Johan Huizinga, The Waning of the Middle Ages (London, I924); D. Weinstein and R.M. Bell, Saints and Society: The Two Worlds of Western Christendom (Chicago, IL, I982). 2. M.B. Petrovich, "The Social and Political Role of the Muscovite Fools-in-Christ: Reality and Image", Forschungen zur osteuropaeischen Geschichte, 25 (1978), pp. 283-296. See also G.P. Fedotov, Svjatye Drevnej Rusi (Moscow, 1990), pp. 198-209. 
They helped to determine perceptions by medieval Russian men and women of the clergy and everything connected with them.

A number of remarks should be made about the specific context of the Russian Orthodox Church. First, in comparison with Catholicism and Protestantism, Orthodoxy was far less closely connected to the economic sphere of life, and never created a political economy as scholars in Catholic Europe did. There, Catholic scholars defined the norms of respectability and labour, and pondered the question of "fair" and "legitimate" prices, what was a justifiable amount of profit, how trade norms should be regulated, and so on. ${ }^{3}$ In medieval Russia, by contrast, it proved hardly possible to create a doctrine of labour comparable with that written by Thomas Aquinas, in which he stated that the main criterion of labour is its public benefit.

During many centuries, Russian theology had "kept silent", not only on questions of the ethics of labour but also on many other practical aspects of religious life. The Protestant idea that a man demonstrates his love of God in his professional life, and that only through professional perfection might a man obtain his reward in the next life, so that a man's professional calling is the real expression of the Celestial will, are alien to Orthodoxy. The famous Russian religious philosopher Nicolas Berdyaev is quite adamant in stating that "[e]conomically productive virtues are by no means characteristic of Russian ethics". ${ }^{4}$

So, labour ethics were expressed in a completely different way from the west European Christian tradition, because of the differences in how labour ethics were conceived of by Orthodoxy and other Christian confessions. The main difference was in the antithetical approach taken to the priority of labour. In Orthodoxy, labour was regarded not in functional terms but in terms of human development; the intention was not to bring about an environmental change, but to bring man closer to God. Furthermore, in Orthodoxy absolute enslavement of any person by labour was widely criticized.'

Second, a detailed and profound historical exploration of the way the ideas of Eastern Christianity were implemented in Russia in practice is complicated by the lack of primary sources that could tell us more about the daily lives of people in medieval and early modern Russia. As a forest country, Russia steadily lost the majority of its primary sources, which were burnt in the frequent conflagrations that broke out. Apart from that,

3. T.B. Koval', "Jetika truda pravoslavija”, Obshestvennye nanki i sovremennost', 6 (I994), p. 56. See also the article elsewhere in this volume by Andrea Caracausi, who discusses agreement concerning "legitimate" wages in labour ideologies in early modern Italy, as well as the contribution by Luca Mocarelli.

4. N.A. Berdyaev, O russkoj filosofii, 2 vols (Sverdlovsk, I99I), II, pp. 26-27.

5. E.A. Tjugashev, "Pravoslavnoe otnoshenie k trudu v zerkale nravstvennogo bogoslovija", Chelovek. Trud. Zanjatost': Nauchno-prakticheskoe periodicheskoe izdanie, 2 (1999), p. 50. 
there are hardly any sources in Russia similar to those in Europe primarily describing working life. In addition, because of the less developed legal role of the Church, there are no documents comparable with the Concordia discordantium canonum $[\text { Decretum Gratiani }]^{6}$ or the papal decrees that can be so helpful to researchers.

\section{RUSSIAN MONASTERIES: ORAETLABORA}

Like the German sociologist Max Weber, who stated that Protestant labour ethics influenced the economic development of Europe, the wellknown Russian religious philosopher Sergei Bulgakov ${ }^{7}$ underlined the importance of religion as a factor determining the value of labour, wealth, and the accumulation of capital. Regarding Christian perspectives on labour, Bulgakov claimed that "[1]abour is invaluable to man as a means of training the will and fighting wicked inclinations and, finally, as an opportunity to serve one's neighbours". ${ }^{8}$

That definition of labour can be considered common to all Christian confessions, but on the historical role of Christianity, "which escalated the awareness of the worth of labour", Bulgakov stressed the great importance of the monasteries as places where economic culture was shaped. ${ }^{9}$ What is more, addressing the specific material on Russian history, he demonstrated that in Russian monasteries attitudes to labour were formed as an educational process, the main goal of which was salvation. Furthermore, although the constructive side of labour seemed very important, the everyday economic side of it was believed to be secondary.

In Russia the following verse from Jeremiah is quite well known: "A curse on him who is lax in doing the Lord's work!" (Jeremiah, 48.10). The concept of "the Lord's work" was understood in a broad sense, as it was possible for all work in general to be pious, including physical labour. Indeed, a specially reverential attitude to labour can be found in early Russian literature, and in his many works St Theodosius (d. I074), of the Kievan Cave Monastery and as one of its first preachers the father of the Russian clergy, as well as a founder of Russian monastic traditions, stated that Russian monks should work and not be lazy.

6. Concordia discordantium canonum [Decretum Gratiani] [Concord of Discordant Canons] was a collection of Church law compiled and written in the twelfth century as a legal textbook by the jurist known as Gratian. It retained legal force in the Catholic Church until i9i 8.

7. Sergei Bulgakov (I87I-I944), religious philosopher and Russian Orthodox priest; he emigrated in 1923 . He was the author of a number of well-known publications, including Philosophy of Economy (1912), Unfading Light (1917), On the Feast of the Gods (1918), and Tragedy of Philosophy (1920).

8. Idem, Pravoslavie (Kiev, I99I), p. 2 I 2.

9. Ol'ga Sidjakina, "Pravoslavnaja jetika truda", http://www.polemics.ru/articles/?articleID= I 92 I \&hideText $=0$ \&itemPage $=$ I, last accessed 6 September 20 I . 
For instance, in his Word about Love and Humility, referring to Paul the Apostle (2 Thessalonians, 3.7-IO), St Theodosius states: "Now I, an unworthy man recalling the commandment of the good Lord, say to you: it is good for us to feed paupers and wayfarers with the fruits of our labour, and not to be idle, going from one cell to another." ${ }^{\circ}$ That is one of the first examples, or perhaps even the very oldest example, in Old Russian literature of a religious text connected with labour ethics and used as a practical guide for daily life in the Russian Orthodox Church. Moreover, St Theodosius elaborated on the theme and developed the first monastic rules of the Kievan Cave Monastery, based on the monastic rules of Theodor Studit, ${ }^{\mathrm{II}}$ a copy of which was sent from Constantinople to Kiev in 1068. Theodor Studit's monastic rules saw labour as an integral part of the life of a monk.

Although St Theodosius's works [Words] were originally addressed to the monks of the Kievan Cave Monastery, they eventually became a guide for all Russian Orthodox believers for a long time. However, at the same time there was another popular view that saw monks as spongers and idlers. A life story of St Theodosius gives a good example of the layman's attitude to a monk. According to that story, once upon a time a prince asked a man to convey St Theodosius to the monastery; the man had no idea who St Theodosius was. On the way to the monastery, the man said: "Listen! You are a monk, you never work, while I am too exhausted to drive a horse. So, let us do it this way: I will have a nap in the cart and you will drive the horse." ${ }^{2}$ That attitude might have been caused by a lack of understanding of what monks actually did, because their real work and activity was hidden from laymen. The story is revealing, for it reflects the negligible participation of Russian monks in everyday labour relations.

In comparison with the situation in Europe where, according to a quite popular view among many historians, from the twelfth century onward a new ideal of labour ethics was formulated after changes in social structure ${ }^{13}$ old beliefs were preserved in medieval Russia for a long time. For example, Jacques Le Goff noted that side by side with economic growth in western Europe the relationship to trade was reconsidered, and the two-way influence changed in both the secular and religious fields. Thus, to lay blame on a merchant, a preacher or theologian would have been required to prove that the merchant was operating maliciously.

I0. Biblioteka literatury Drevnej Rusi, 20 vols (St Petersburg, I997-), I, pp. 434-435.

I I. Theodor Studit (also called Theodore the Studite or St Theodore of Stoudios, 759-826), a Byzantine monk and abbot of the Stoudios monastery in Constantinople. He played a major role in the revivals both of Byzantine monasticism and of classical literary genres in Byzantium. I 2. Biblioteka literatury Drevnej Rusi, I, pp. 392-393.

13. Catharina Lis and Joseph Ehmer, "Introduction: Historical Studies in Perceptions of Work", in Josef Ehmer and Catharina Lis (eds), The Idea of Work in Europe from Antiquity to Modern Times (Farnham, 2009), pp. 9-1 I. 
Under the influence of those changes in social structure, the relationship with time changed, as expressed in the arrival of the public clock mounted in a tower. A reliable clock mechanism had been invented by the end of the thirteenth century, but it had begun to replace the church bell only from the mid-fourteenth century. Thenceforward, human life was no longer measured by the times for prayer as if completely belonging to God, but by the natural hours reflected by a mechanism devised by human hands. ${ }^{\mathrm{I}}$ Neither man's relationship to trade nor his relationship to time changed in Russia. Although the first clock tower in Russia appeared a little later, at the beginning of the fifteenth century, time was determined as before, by liturgical tradition. That can be explained on the one hand by the economic conditions peculiar to Russia, and on the other by the unified traditions of the monasteries, which continued to live by the monastic rules of Theodor Studit throughout the thirteenth and fourteenth centuries. ${ }^{\text {Is }}$

The fact that the Church was not very actively involved in economic life might also explain why the traditional ethics of medieval Russia survived for so long, and we should not forget that Russia underwent a general economic decline after the Mongol invasion. ${ }^{16}$ However, the most important reason is still principally the different view taken by the Russian Orthodox Church in relation to labour. St Joseph of Volotsk (d. I I I ) explained the necessity for a monk's labour in the same way as St Theodosius had. In the monastic rules of St Joseph's monastery he required the monks to work constantly, praying at the same time: "a monk can never be idle". St Joseph believed that labour, as a "common deed", was an essential of faith, realized in generous actions, and was a prayer materialized. Moreover, the principle of mandatory labour, proclaimed in all Russian friaries, influenced the layman's attitude to labour, and the monastic way of life contributed nothing to the growth of capitalism nor to any other economic system. The head of the Russian Orthodox Church, Metropolitan Daniel (d. I 547), taught his parish in accordance with classical Orthodox views on labour. In one of his sermons he stated:

[This] does not mean that Christians should not work, plough, buy and sell, manage slaves, and build homes. We can do all this, but we must not grow too attached to anything or worry too much about anything, putting our hope in God, who alone can bless our labour with success and help us against all enemies.

14. Jacques Le Goff, Time, Work and Culture in the Middle Ages (Chicago, IL, I980), pp. $35-52$.

I s. Arhimandrit Avgustin, “Studijskij Monastyr' i Drevnjaja Rus' (Iz Istorii Russko-Vizantijskih Cerkovnyh Svjazej)", Al'fa i Omega, 3 (2008), pp. 332-345.

16. D. Miller, "Monumental Building as an Indicator of Economic Trends in Northern Rus' in the Late Kievan and Mongol Periods, II38-I462", American Historical Review, 94 (1989), pp. 360-390. 
While tilling the soil we must reflect and also look after spiritual fruit; in buying and selling we must be guided by truth and honesty; $[\ldots]$ we must build homes and property in order to help the poor. ${ }^{17}$

In connection with the facts considered above it is interesting to observe also the history of monastic colonization. The second half of the fourteenth century was the time when a very important process known as "the monastic colonization of the north" began in Russia. Monks went to sparsely populated and isolated areas in the north and north-east of Russia and founded monasteries there. The process continued throughout the fifteenth, sixteenth, and seventeenth centuries. In fact, in seventeenthcentury Russia, the hermit's life was a widespread practice among monks, and more and more small monasteries [pustyn'] and hermitages [skit] appeared as monastery subsidiaries that had stricter rules and regulations governing the everyday life of the monks. ${ }^{18}$ Such small monasteries, led by hermits, produced no commercial goods and never undertook the task of creating large-scale enterprises or estates. Instead they relied for their existence on charitable donations. Certainly, the monks in pustyns and skits worked constantly, providing themselves with the bare necessities, but the idea of work - its educational purpose - remained unchanged.

It is also necessary to consider that in the conditions of the severe Russian climate, the country's huge wooded areas and the scarcity of natural resources, the constant arduous toil of the monks yielded an insignificant return. For them it was a question of survival, not of life in abundance. All of that strongly supports the idea of a minor role for the monasteries in the economic life of Old Russia. In each of the places where monasteries were found, there was also a colony of peasant households surrounding the monasteries. The Russian nineteenth-century historian, Vasilii Klyuchevsky, who studied the mechanism of the colonization process, concluded that "sometimes monks were followed by peasants and sometimes it was the other way around, but the connection between one and the other is clear". Furthermore, "a desert monastery served both the religious and economic needs of migrants, and along with it they used their labour and increased the number of brothers with them". ${ }^{9}$

However, scholars today view the question of the influence of monastic colonization on the opening up of new lands in the north in a different way. They emphasize that monastic colonization contributed to the opening up of the northern lands, but culturally and politically rather than economically.

17. Mitropolit Makarij (Bulgakov), Istorija Russkoj Cerkvi, 7 vols (Moscow, I996), IV (I), pp. $385-386$.

I8. I.K. Smolich, Russkoe monashestvo, 988-1917 (Moscow, 1997), p. I3.

I9. V.O. Klyuchevsky, Sochinenija, 9 vols (Moscow, 1987), II, p. 453. 
For instance, at the turn of the fifteenth century Russian princes distinctively admired the eparchy [church diocese] of Perm, a region to the north-west of the Ural mountains. From the late fourteenth century, when the eparchy was founded there, the bishops of Perm had unconditionally supported the princes in Moscow and helped them in civilizing the north-eastern regions of Russia. It is suggested that in the fifteenth century the Perm eparchy existed as a semi-independent state, and that its bishops were vassals of the Moscow prince. ${ }^{20}$

The monastery of St Trifon of the Pechenga, founded in I 520-I530 at a latitude of 70 degrees North, was the most northerly Orthodox monastery and is a brilliant illustration of the fact that monastic colonization had only a secondary economic function. The monastery was traditionally regarded as very significant and influential in its northern situation. Its founder, St Trifon, had been an active merchant, who made connections with Russian traders, local inhabitants, and Scandinavian merchants. His trading activity seemed not to be an end in itself, but rather a tool for collecting money for the foundation of the future monastery, and, what is more, the involvement in trade of the local inhabitants contributed to the dissemination of Christianity among them too. The historian V.L. Derzhavin has emphasized that, although monastic colonization developed simultaneously with industrial colonization, the second obviously prevailed, for it provided a material basis for St Trifon's monastery, and the fact that this economic activity preceded the foundation of the Pechenga monastery is itself proof of that argument. ${ }^{21}$

Nevertheless, the laws of economic life during an era of feudalism and the general religiosity of society meant that, as spiritual corporations, monasteries received all kinds of donations and contributions, and possessions of land were the pivotal form of them. The growth of monastic land tenure contributed to strengthening the economic role of monasteries in public life, not only in territorial colonization but also in the organization of manufacturing. One such aspect of the economic activity of monasteries which began to develop was that of affording credit to peasants, while I.K. Smolich underlines the fact that, due to the constant growth of monastic possessions and the development of a monastic economy, Russian monasteries frequently handled many different products, in quantities surpassing the monastery's own requirements, and that forced them to become involved in trade. ${ }^{22}$ Indeed, a number of

20. G.N. Chagin, "Hristianizacija Permi Velikoj Cherdyni i ejo rol' v razvitii gosudarstvennosti i kul'tury v XV-XVII v.”, in Vehi hristianskoj istorii Prikam'ja: Materialy chtenij, posvjawjonnyh 540-letiju krewenija Permi Velikoj (Perm, 2003), pp. 5-18.

2I. V.L. Derzhavin, Severnyj Murman v XVI-XVII vv. (K istorii russko-evropejskih svjazej na Kol'skom poluostrove) (Moscow, 2006), p. I32.

22. Smolich, Russkoe monashestvo, p. 148 . 
studies have noted that some of the major monasteries and episcopal cathedrals became economically prosperous during the fifteenth century.

A monastic economy differed much more in terms of stability compared with a secular economy; it was more involved in commodity-money relations, with considerable sums of money being accumulated in monasteries. ${ }^{23}$ The largest monasteries of the time played a notable role in social organization, were strong economic organisms, and made a significant impact on the economic life of their neighbourhoods. One particular example was the Solovetsky monastery, founded in I429, which extended its production and commercial activity until it became an economic and political centre of the White Sea region. The Solovetsky monastery's business activities included salt works (in the I660s it owned fifty-four of them), seafood production, trapping, fishery, mica works, ironworks, and pearl works, which made many people dependent on the monastery. An outstanding role in the development of such a powerful centre, created in the extremely difficult conditions of the north of the country, was played by the famous saint, Abbot Philip Kolychev (I 507-I 569), a future Russian metropolitan who dared to oppose openly Ivan the Terrible's authority and was murdered. ${ }^{24}$

Nevertheless monasteries such as that at Solovetsky were exceptions, for, as noted above, Russian monasteries generally existed in adverse conditions, and the majority of them merely managed to survive. The back-breaking work performed by the monks and others provided a small surplus sufficient for them to live on but insufficient to allow much growth. In such conditions, economic mechanisms were insufficient to allow capitalism to emerge.

\section{RUSSIAN SOCIAL ORDER: SOCIALLY USEFUL LABOUR BY EVERYONE}

In his book on medieval Moscow monasteries L.A. Beliaev, a historian and archaeologist, concludes, justifiably, that most modern ideals of Russian culture can be traced back to the monastic perception of the world, and those ideals include that of constant labour, especially that which is socially useful. ${ }^{25}$ Monastic influence on these traditions could be found in early medieval times.

Another interesting and remarkable fact is that the Russian Orthodox call for labour, addressed to monks in the eleventh century, became

23. N.V. Sinicyna, "Russkoe monashestvo i monastyri. X-XVII vv.", in Pravoslavnaja enciklopedija. Russkaja Pravoslavnaja Cerkov" (Moscow, 2000), pp. 305-324.

24. E.V. Romanenko, Povsednevnaja zhizn' russkogo srednevekovogo monastyrja (Moscow, 2002), pp. 64-65.

25. L.A. Beliaev, Drevnie monastyri Moskvy (kon. XIII-nach. XV vv.) po dannym arbeologii (Moscow, 1994), p. 7. 
popular among the nobility too. Grand Duke Vladimir Monomakh (d. I I25) left a curious set of instructions to his sons, dated I I 7 , in which he gave them a great deal of practical advice, reinforced with examples from his own experience. In his well-known Pouchenie [Lecture] a precept to work is already mentioned in the introduction and anticipates all other admonitions of the Grand Duke: "My children, or anyone else reading this document, do not laugh, and those of my children who find it pleasing, 1 et them take it to heart and not be lazy, but work." ${ }^{26}$ This claim formed a vector of the attitude to labour of later nobles: in medieval Russian society it was unnatural for the nobility to do hard physical work, but it was possible in difficult circumstances. For example, a remarkable governor of the medieval period, Ivan III, creator of the unified Russian state, participated personally in extinguishing fires in Moscow. The historian Nikolaj Borisov carefully collected such cases: sometimes in extinguishing the fires the great prince was assisted by other nobles [deti boyarskie], and once even by his son. ${ }^{27}$

In the mid-sixteenth century the Velikie Minei Chetii [The Great Menaion Reader] was compiled. This fundamental book is a collection of biblical books with interpretations of exordiums, originals or translations of hagiographies of Russian saints, and works by the Church fathers and Russian ecclesiastical writers. It was put together in the I 530 s to I540s under the supervision of Metropolitan Macarius, the head of the Russian Orthodox Church. Macarius decided to compile The Great Menaion Reader in order to centralize the cult of the Russian saints and to consolidate Church ideology.

For 8 May it includes the Slovo [Story] from the Lives of the Holy Fathers to show how beneficial it is to work. The Slovo relates a parable in which an old man declares: "If we strive to work and we do not become lazy, we will be saved." He then tells the story of a rich landowner who wanted to teach his sons to work. The landowner said that there is a certain day in the year and those who are found to be working on that day will become rich. "But in my old age I have forgotten which day it is exactly", he said. "Therefore do not be lazy on any day. Work so that you are not caught idle on this blessed day, otherwise you will work in vain the whole year." The old man then concluded with these words: "And so it is with us - if we will work we will always find the path to salvation." 28

Although The Great Menaion Reader addressed a limited number of readers, its compilation amounted to the design of a special programme and a guide for the Russian Orthodox Church, proclaiming concrete ideas. Obviously, labour was one ideal, and that was addressed to the whole of society, from peasants to clergy and the nobility. It is interesting that

26. Biblioteka literatury Drevnej Rusi, I, pp. 456-457.

27. N.S. Borisov, Povsednevnaja zhizn' srednevekovoj Rusi nakanune konca sveta (Moscow, 2004), pp. I38-I42.

28. Biblioteka literatury Dreonej Rusi, XII, pp. 236-237. 
on 8 May the Russian Orthodox Church celebrates the life of St Arsenij Pecherskij, who lived in the fourteenth century and was very diligent in his work. Indeed, the nickname "Hard-Working" was appended to his name. I believe that the inclusion of Slovo on 8 May could be connected with the feast day of St Arsenij Pecherskij the Hard-Working. The practice of combining such events was at least usual in medieval and early modern society.

A formidable presage of the destruction of the world was the most important cultural phenomenon characterizing the era of the Russian autumn of the Middle Ages. Alarming tensions in everyday life in the fourteenth and early fifteenth centuries turned into a constant feeling of doom as the year 7000 of the Byzantine calendar approached (it equates to AD ${ }_{4} 42$ in the Western calendar). However, it was not believed that all life would cease to exist on the eve of the Last Judgement because the Orthodox eschatology had exalted and enlightened features. Nevertheless, a confident faith that the final days of human existence were at hand was shared by the majority of people living then, and was what mainly determined their attitudes and actions. Thus, the Church calendar showing the dates of Easter [paschalija], which was usually worked out in advance, was constructed only for the years prior to I492. Even after the Day of Doom failed to materialize, people still thought it would. According to widespread representations at that time, expectations were transferred to other septenary dates: the years 7070 (AD i 562) or 7077 (AD i 569). It is interesting to note that at the end of the fifteenth century new paschalija were calculated for a period of only seventy years. ${ }^{29}$

Under those circumstances the Church did not encourage its spiritual sons to leave their labour and concentrate only on repentance and ascetic life; on the contrary, the Church insisted that constant labour was necessary and extremely important. For instance, in the first half of the sixteenth century Dositheus Toporkov, the author of Volokolamsk: Lives of the Holy Fathers, stated that in contemporary times, before the end of the world should come, it was more than important than ever "to be obedient, to work, to pray and keep the fast to the best of our ability, and also to be humble, considering oneself beneath all others because this is the principal virtue". ${ }^{\circ}$

The Russian Church not only urged its flock to work, it also protected the interests of those who did. In relation to that, it is worth mentioning the famous apocryphal story The Wanderings of Our Lady through Hell, about which Ivan Karamazov speaks in Dostoevsky's novel, The Brothers Karamazov. This apocryphal story, which was of Greek origin, had been known in Russia since the twelfth century and was one

29. A.V. Karavashkin and A.L. Jurganov, Opyt istoricheskoj fenomenologii. Trudnyj put' $k$ ochevidnosti (Moscow, 2003), pp. 68-i I s.

30. Biblioteka literatury Drevnej Rusi, IX, pp. 32-33. 
of the most popular tales in Russian literature. In the seventeenth and eighteenth centuries, the story was rewritten and recast several times by the Old Believers. ${ }^{3 \mathrm{I}}$ In the story, the archangel Michael accompanies the Virgin on her walk through hell and shows her the torments of the sinners. Among the sinners shipped in along the fiery river, there are those who as the archangel says - "reaped another's fields and picked another's fruit, those who eat at the expense of another's work". ${ }^{22}$ In addition, in his writings Metropolitan Daniel emphasized that servants must be managed with humility and gentleness, they must be forgiven as one would forgive one's own children, but those who misbehave ought to be kept in fear, although in his heart their master must secretly forgive them.

\section{THE RUSSIAN HOUSEHOLD: THE DOMOSTROI}

The Domostroi $i^{33}$ is one of the most important primary sources, containing a large quantity of useful information about work ethics in late medieval and early modern Russia. ${ }^{34}$ Even in the mid-nineteenth century the Domostroi was still in force, being widespread among peasants, who tended to follow its rules because they felt them to be true examples of Orthodoxy and pure wisdom..$^{35}$

It is hard to determine the exact date on which the Domostroi was created, although historians believe the material was written at some time between 1475 and I 560 . Nowadays, the most widely held point of view states that the Domostroi was written in the mid-sixteenth century, but no later than the 1550 s. $^{36}$ The text is preserved in two versions, ${ }^{37}$ of one of

3 I. Old Believers [Russian: starovery or staroobriadtsy] were participants in the movement for Russian spiritual culture, which started in the 1650s, The Old Believers split from the official Russian Orthodox Church in protest at Church reforms introduced by Patriarch Nikon. Old Believers continue liturgical practices which the Russian Orthodox Church maintained before those reforms were implemented.

32. Biblioteka literatury Dreonej Rusi, III, pp. 3 I4-3 I 5.

33. The word Domostroi consists of two Russian words: dom (house) and stroitel'stvo (management). It can be translated as "domestic order" or "household management". Originally it was a loan translation of the Greek oikonomia. See T.V. Chumakova, $V$ chelovecheskom zhitel'stve mnozi obrazy zrjatsja: Obraz cheloveka v kul'ture Drevnej Rusi (St Petersburg, 200I), p. I34.

34. Carolyn Johnston Pouncy (ed. and transl.), The Domostroi: Rules for Russian Households in the Time of Ivan the Terrible (Ithaca, NY, 1994); Klaus Müller, Altrussisches Hausbuch "Domostroi" (Leipzig, 1987).

35. A.S. Orlov, "Domostroi", in Istorija russkoj literatury, io vols (Moscow, I945), II, p. 445. 36. L.P. Najdenova, "Svoi i chuzhie v Domostroe. Vnutrisemejnye otnoshenija v Moskve XVI veka", in Chelovek v krugu sem'i. Ocherki po istorii chastnoj zhizni v Evrope do nachala novogo vremeni (Moscow, I996), pp. 290-295.

37. Some historians have identified a third version of the Domostroi, of which we have three copies, created as the result of unskilful mechanical copying. See V.V. Kolesov, "Domostroi: Kommentarii”, in Biblioteka literatury Dreonej Rusi, X, p. 58 . 
which we have forty-four copies and of the other forty-five, the majority of them made in the seventeenth century. Although the question of the origins of the Domostroi has not been completely resolved, we have some clear evidence about them. ${ }^{38}$ First, the sources that inspired the authors of the Domostroi include the collections of moralizing texts, written on the basis of the teachings [pouchenie] of a number of clerics: Izmaragd, Zlatoust [teachings of John Chrysostom], Zolotaya Tsep', and other moralizing doctrines which appeared in Russia at some time later than the eleventh century.

In the mid-seventeenth century 67 per cent of the Domostroi manuscripts signed by their owners belonged to office employees, 22 per cent to clergy, and I I per cent to private citizens, including artisans and merchants. ${ }^{39}$

Archpriest G.V. Florovskij (I 893-I979), a Russian religious philosopher and historian, states that the Domostroi "hardly depicts everyday life, a realistic picture [...]. This book is didactic, not descriptive. It outlines a theoretical ideal; it does not portray everyday reality." 40 That argument implies that we should compare the Domostro $i$ with traditional Russian Orthodox didactic literature.

The historian L.P. Najdenova stresses that the main feature of the Domostroi is its desire to Christianize all spheres of the daily life of medieval Russians. She considers the Domostroi a peak in religious understanding of the world, after which the influence of the religious perspective and world view declined, something reflected too in the secularization of Russian culture which had started in the seventeenth century. So it cannot be a mere coincidence that most copies of the Domostroi originated in the seventeenth century, when strong religious traditions co-existed with cultural secularization. The real author of the Domostroi is unknown, but the most widespread version was edited by Archpriest Sylvester, who lived during the reign of Ivan the Terrible, and was well known as Ivan's tutor. More specifically, Sylvester created the final edition of it as a great literary monument and historical source. The Domostroi is the product of secular literature and is addressed to life in the secular world, but it is based on a religious system of values. ${ }^{4 \mathrm{I}}$ The idea of a truly ethical working life is central to the Domostroi.

38. R. Jagoditsch, "Zu den Quellen des altrussischen 'Domostroi”, in Österreichische Beiträge zum V. Internationalen Slavisten Kongress (Graz, I963), pp. 40-48.

39. C.J. Pouncy, "The Origins of the Domostroi: A Study in Manuscript History", The Russian Review, 46 (1987), pp. 357-373.

40. G.V. Florovskij, Puti russkogo bogoslovija (Parizh, I983), p. 26.

4I. In this respect the Domostroi is similar to German household literature. See Torsten Meyer, "Cultivating the Landscape: The Perception and Description of Work in I6th- to I 8th-Century German 'Household Literature' (Hausväterliteratur)”, in Ehmer and Lis, The Idea of Work in Europe, p. 244. 
According to the Domostroi, any rich burgher owed his status not to his noble birth, but rather to his labour and personal initiative. All work should be done "with prayer and with kind conversation or in silence", and "without procrastination". If "during any labour there sounds a word that is idle, indecent, or blasphemous, or said with a grumble or snicker, or there is nasty and wanton talk, God's grace will shrink from such labour, angels will depart in grief, and wicked demons will rejoice". ${ }^{42}$ The Domostroi emphasizes that one of the major duties of an owner was not to withhold payment to the worker. The Domostroi dictates remarkable rules regarding work clothes: "And a word to all servants: always work in old clothes, but in a clean everyday dress when before the master or in public and in your best dress on holidays and among gentlefolk, or if going out with the master or mistress". ${ }^{43}$

There is a separate article about female work in the Domostroi which is almost exclusively to do with housekeeping, the main argument of the article being that the mistress of the house should never be without work to do. She should always be able to give orders to the servants and she herself should always be busy. Illness was the only valid reason to stop working. The image described in the Domostroi of a hard-working wife who is religious, not talkative, cares for the poor, and is entirely devoted to her husband might have originated in The Book of Proverbs. ${ }^{44}$

The Domostroi contains explicit advice for masters, but none for wage workers. It is a guide for people "free by God", so it is a collection of the rules that are addressed to a sufficiently prosperous family who live in the city. ${ }^{45}$ Problems of how to hire workers, how to produce goods one could sell, or how to regulate the commercial affairs of household life were not discussed in its pages. The Domostroi did not instruct its readers in how to sell, but it did advise them how to buy. According to the text, a husband was responsible for the wholesale stocking of the products from his fields, meadows, fruit and vegetable gardens, for beekeeping, fisheries, and his seasonal bargainings with Russian and foreign merchants, and for purchasing such goods as spices, lemons, grapes, melons, and watermelons; the book touched too on the storage of all such products.

The main goal of the Domostroi was to create an ideal internal household environment within the family. An ideal family's house was compared to heaven, quite a common feature of medieval consciousness and literature. For example, the Russian academic Dmitrii Likhatchyov has noted that:

$[\ldots]$ this ideal acts as a regulator of real life, and if it is put into practice at home, if it becomes a part of all the details of daily life, of behaviour within the family

42. Biblioteka literatury Dreonej Rusi, X, pp. $136-137$.

43. Ibid., pp. I40-I4I.

44. Kolesov, "Domostroi: Kommentarii", p. 585.

45. A. Bogdanov, "Nravy Domostroevoj ulicy", Nanka i religija, s (1993), p. 5 I. 
and home, and if there is in everything the moderation it demands - then the ideal almost becomes reality. ${ }^{46}$

It is interesting that in the Domostroi a clear distinction was made between the words "labour" and "work". "Work" is defined as forced hard labour, while "labour" means godly virtuous activity for the welfare of a man and his intimates, such as his family, rather than people in general. For example, the word "labour" is used when the author of the Domostroi refers to children: "Do not forget the labour of your father and mother, who cared for and worried about you. Give them a peaceful old age and look after them, as they looked after you." 47

As we can see, the term "labour" closely approximates to the definition of "pious labour". According to the Domostroi, labour is the greatest virtue, both physical and moral. The term "pious labour" is very significant in the document. Apart from the common idea that "nobody will be recompensed without labour", "pious labour" underlines honest service to the state, care for a wife and family, and a servant's care about the master's interest. The raising of children is also referred to as "pious labour".

According to the Domostroi, labour is not a goal in itself. It is a tool to stand as prayer and to serve God on earth. Everyone's duty is to pray to God at home and in the church, and to serve God by building his life and household according to divine rules. The Domostroi is not an actual normative document, because it establishes no juridical norms, only moral ones, basing them on practicalities, seeking to show that by living correctly a man lives virtuously and profitably. ${ }^{48}$ In connection with that, Najdenova draws attention to the fact that Archpriest Sylvester, in a letter to his son Anfim, not only instructs him in how to live but also gives him advice on how to become a successful businessman. The secret is to be honest and benevolent with business partners.

In the Orthodox tradition, God gives wealth to people for temporary usage and places additional obligations of charity and goodness on its guardians. It is worth noting that from the Orthodox point of view, material wealth is not harmful in itself, for poverty cannot elevate one's soul. Wealth and poverty are quite neutral. However, a strong desire for wealth, a cult of it, is private and social poison. In the Domostroi the same attitude is presented with regard to labour, which it is said can bring no wealth, but only "possessions" [imenie], and "wealth" is depicted as a temptation. As a result, the book confirms the principle of temperance as

46. V.V. Shaposhnik, "Sem'ja kak model' gosudarstvennogo ustrojstva v Moskovskoj Rusi XVI v. (po pamjatnikam pis'mennosti)", Trudy kafedry istorii Rossii s drevnejshib vremen do XX veka (St Petersburg, 2006), pp. 538-556.

47. Biblioteka literatury Dreonej Rusi, X, pp. I34-135.

48. L.P. Najdenova, "Svoi i chuzhie v Domostroe", Rodina, 6 (1997), p. 27. 
a basis of ascetics - salvation can be reached not only through an ascetic life but also in a righteous, tempered life in a secular world.

To conclude our discourse about the Domostroi, it is necessary to emphasize that it is impossible to answer definitively the question of whether the Domostroi adds something new or whether it is a collation of everything previously thought about labour in Russian Orthodoxy. Unfortunately, no historical sources similar to the Domostroi and which might have illuminated labour ethics in great detail have survived from earlier periods. However, one thing is absolutely clear. Even if the Domostroi contained some private innovations, on the whole, in its major ideological component, it remained firmly rooted in earlier traditions. Furthermore, it is just as clear that the ideas of the clergy about the ethics of work spread to the nobility and then to the average sixteenth- and seventeenth-century household, such as those addressed in the Domostroi. During those years Russian culture continued to retain its most powerful religious component.

\section{CONCLUSION}

The religious aspect of labour ethics in medieval and early modern Russia, defined at first exclusively by the clergy and above all by monks, was based on traditional Orthodox representations, which in turn stated that the main purpose of work was to attain salvation. In the monasteries of Russia attitudes to labour were formed as an educational process. Further, work should certainly have some creative value, although the economic aspect of work was clearly thought of as secondary. Owing to such views, and because of the natural conditions and climate of the country, the monastic way of life did not contribute to the growth of capitalism, nor to other economic systems. Russia's economic base was in any case weak. There is one further important remark to be made: Russia's social order decreed that everybody must work, although not necessarily physically, and that work should be socially useful. 